\title{
Sepsis pada Neonatus (Sepsis Neonatal)
}

\author{
Titut S Pusponegoro
}

\begin{abstract}
Sepsis neonatal adalah sindrom klinik penyakit sistemik, disertai bakteremia yang terjadi pada bayi dalam satu bulan pertama kehidupan. Angka kejadian sepsis neonatal adalah 1-10 per 1000 kelahiran hidup. Sepsis neonatal dapat terjadi secara dini, yaitu pada 5-7 hari pertama dengan organisme penyebab didapat dari intrapartum atau melalui saluran genital ibu. Sepsis neonatal dapat terjadi setelah bayi berumur 7 hari atau lebih yang disebut sepsis lambat, yang mudah menjadi berat dan sering menjadi meningitis. Sepsis nosokomial terutama terjadi pada bayi berat lahir sangat rendah atau bayi kurang bulan dengan angka kematian yang sangat tinggi. Karena masih tingginya angka kematian sepsis neonatal, tatalaksana yang utama adalah upaya pencegahan dengan pemakaian proteksi di setiap tindakan terhadap neonatus, termasuk pemakaian sarung tangan, masker, baju dan kacamata debu serta mencuci segera tangan dan kulit yang terkena darah atau cairan tubuh lainnya.
\end{abstract}

Kata kunci: sepsis dini - sepsis lambat - sepsis nosokomial.

$S$ epsis neonatal adalah sindrom klinik penyakit sistemik, disertai bakteremia yang terjadi pada bayi dalam satu bulan pertama kehidupan. Angka kejadian sepsis neonatal adalah 1-10 per 1000 kelahiran hidup, dan mencapai 13-27 per 1000 kelahiran hidup pada bayi dengan berat $<1500$ gram. Angka kematian 13-50\%, terutama pada bayi prematur (5-10 kali kejadian pada neonatus cukup bulan) dan neonatus dengan penyakit berat dini. Infeksi nosokomial pada bayi berat lahir sangat rendah, merupakan penyebab utama tingginya kematian pada umur setelah 5 hari kehidupan.

\section{Patofisiologi}

Sesuai dengan patogenesis, secara klinik sepsis neonatal dapat dikategorikan dalam:

Sepsis dini, terjadi pada 5-7 hari pertama, tanda distres pernapasan lebih mencolok, organisme penyebab

Alamat korespondensi:

Dr. Titut S Pusponegoro Sp.A

KK Perinatologi - Rumah Sakit Anak \& Bunda Harapan Kita. Jl. Letjen S. Parman, Jakarta

Telpon: (021) 7401139 . Fax.: (021) 5601816 penyakit didapat dari intrapartum, atau melalui saluran genital ibu. Pada keadaan ini kolonisasi patogen terjadi pada periode perinatal. Beberapa mikroorganisme penyebab, seperti treponema, virus, listeria dan candida, transmisi ke janin melalui plasenta secara hematogenik. Cara lain masuknya mikroorganisme, dapat melalui proses persalinan. Dengan pecahnya selaput ketuban, mikro-organisme dalam flora vagina atau bakteri patogen lainnya secara asenden dapat mencapai cairan amnion dan janin. Hal ini memungkinkan terjadinya khorioamnionitis atau cairan amnion yang telah terinfeksi teraspirasi oleh janin atau neonatus, yang kemudian berperan sebagai penyebab kelainan pernapasan. Adanya vernix atau mekoneum merusak peran alami bakteriostatik cairan amnion. Akhirnya bayi dapat terpapar flora vagina waktu melalui jalan lahir. Kolonisasi terutama terjadi pada kulit, nasofaring, orofaring, konjungtiva, dan tali pusat. Trauma pada permukaan ini mempercepat proses infeksi. Penyakit dini ditandai dengan kejadian yang mendadak dan berat, yang berkembang dengan cepat menjadi syok sepsis dengan angka kematian tinggi. Insidens syok septik 0,1$0,4 \%$ dengan mortalitas $15-45 \%$ dan morbiditas kecacatan saraf.

Umumnya terjadi setelah bayi berumur 7 hari atau lebih. 
Sepsis lambat mudah menjadi berat, tersering menjadi meningitis. Bakteri penyebab sepsis dan meningitis, termasuk yang timbul sesudah lahir yang berasal dari saluran genital ibu, kontak antar manusia atau dari alat-alat yang terkontaminasi. Di sini transmisi horisontal memegang peran. Insiden sepsis lambat sekitar 5-25\%, sedangkan mortalitas 10-20\% namun pada bayi kurang bulan mempunyai risiko lebih mudah terinfeksi, disebabkan penyakit utama dan imunitas yang imatur.

\section{Mikroorganisme Penyebab Sepsis}

Organisme penyebab sepsis primer berbeda dengan sepsis nosokomial.

Sepsis primer biasanya disebabkan: Streptokokus Grup B (GBS), kuman usus Gram negatif, terutama Escherisia coli, Listeria monocytogenes, Stafilokokus, Streptokokus lainnya (termasuk Enterokokus), kuman anaerob, dan Haemophilus influenzae. Sedangkan penyebab sepsis nosokomial adalah Stafilokokus (terutama Staphylococcus epidermidis), kuman Gram negatif (Pseudomonas, Klebsiella, Serratia, dan Proteus), dan jamur.

Faktor Risiko untuk Terjadinya Sepsis Neonatal ialah:

- Prematuritas dan berat lahir rendah, disebabkan fungsi dan anatomi kulit yang masih imatur, dan lemahnya sistem imun,

- Ketuban pecah dini (>18 jam),

- Ibu demam pada masa peripartum atau ibu dengan infeksi, misalnya khorioamnionitis, infeksi saluran kencing, kolonisasi vagina oleh GBS, kolonisasi perineal dengan E. coli,

- Cairan ketuban hijau keruh dan berbau,

- Tindakan resusitasi pada bayi baru lahir,

- Kehamilan kembar,

- Prosedur invasif,

- Tindakan pemasangan alat misalnya kateter, infus, pipa endotrakheal,

- Bayi dengan galaktosemi,

- Terapi zat besi,

- Perawatan di NICU (neonatal intensive care unit) yang terlalu lama,

- Pemberian nutrisi parenteral,

- Pemakaian antibiotik sebelumnya, dan

- Lain-lain misalnya bayi laki-laki terpapar 4x lebih sering dari perempuan

\section{Daya Pertahanan Tubuh}

Lemahnya pertahanan tubuh pada bayi kurang bulan atau pada bayi cukup bulan risiko tinggi disebabkan oleh

\section{Sistem Imunitas Seluler}

Sel polimorfonuklear mempunyai kemampuan kemotaksis terbatas, menurunnya mobilisasi reseptor permukaan sel, kemampuan bakterisidal yang amat terbatas, dan fagositosis normal.

- Semua komponen komplemen kurang, terutama pada bayi kurang bulan juga, disertai kurangnya produksi zat kemotaktik opsonin.

- Sel limfosit T yang berfungsi dalam imunitas seluler telah normal pada gestasi muda, tetapi belum dapat memberikan respons terhadap antigen asing yang spesifik, hal ini menyebabkan bayi rentan terhadap infeksi jamur dan virus, meningkatnya jumlah sel T supresor, dapat mengurangi produksi antibodi sewaktu antenatal.

- Sel limfosit B dalam makrofag membelah menjadi sel memori atau menjadi sel plasma yang menghasilkan antibodi.

\section{Sistem Imunitas Humoral}

Kadar IgG pada neonatus tergantung dari transport aktif melalui plasenta oleh karena semua tipe IgG dari ibu dapat ditransport ke janin sedangkan IgM, IgA dan IgE tidak melalui plasenta, karena itu pada neonatus jumlahnya kurang. Antibodi yang ditransfer ke janin, akan menjadi pelindung terhadap infeksi spesifik yang pernah diderita ibu sebelumnya. Secara kuantitatif, jumlah IgG jelas kurang pada bayi berat lahir sangat rendah, karena sebagian besar IgG ditransfer melalui plasenta sesudah 32 minggu kehamilan; maka jumlah IgG pada bayi kurang bulan sangat rendah dibanding bayi cukup bulan. Jumlah ini berkurang pada beberapa bulan pertama sesudah lahir, keadaan ini disebut hipoimunoglobinemia fisiologis pascanatal. Hal inilah yang merupakan faktor risiko terjadinya infeksi nosokomial pada masa neonatal, terutama untuk bayi berat lahir sangat rendah atau bayi kurang bulan. 


\section{Diagnosis}

\section{Manifestasi klinik}

Diagnosis dini sepsis ditegakkan berdasarkan gejala klinik dan terapi diberikan tanpa menunggu hasil kultur. Tanda dan gejala sepsis neonatal tidak spesifik dengan diagnosis banding yang sangat luas, termasuk gangguan napas, penyakit metabolik, penyakit hematologik, penyakit susunan syaraf pusat, penyakit jantung, dan proses penyakit infeksi lainnya (misalnya infeksi TORCH = toksoplasma, rubela, sitomegalo virus, herpes).

Bayi yang diduga menderita sepsis bila terdapat gejala:

- Letargi, iritabel,

- Tampak sakit,

- Kulit berubah warna keabu-abuan, gangguan perfusi, sianosis, pucat, kulit bintik-bintik tidak rata, petekie, ruam, sklerema atau ikterik,

- Suhu tidak stabil demam atau hipotermi,

- Perubahan metabolik hipoglikemi atau hiperglikemi, asidosis metabolik,

- Gejala gangguan kardiopulmonal gangguan pernapasan (merintih, napas cuping hidung, retraksi, takipnu), apnu dalam 24 jam pertama atau tiba-tiba, takikardi, atau hipotensi (biasanya timbul lambat),

- Gejala gastrointestinal: toleransi minum yang buruk, muntah, diare, kembung dengan atau tanpa adanya bowel loop.

\section{Pemeriksaan laboratorium}

\section{- Hematologi}

Darah rutin, termasuk kadar hemoglobin $\mathrm{Hb}$, hematokrit Ht, leukosit dan hitung jenis, trombosit. Pada umumnya terdapat neutropeni PMN <1800/ $\mu$ l, trombositopeni $<150.000 / \mu l$ (spesifisitas tinggi, sensitivitas rendah), neutrofil muda meningkat $>1500 / \mu$, rasio neutrofil imatur : total $>0,2$. Adanya reaktan fase akut yaitu CRP (konsentrasi tertinggi dilaporkan pada infeksi bakteri, kenaikan sedang didapatkan pada kondisi infeksi kronik), LED, GCSF (granulocyte colonystimulating factor), sitokin IL-1ß, IL-6 dan TNF (tumour necrosis factor).

- Biakan darah atau cairan tubuh lainnya (cairan serebrospinalis) serta uji resistensi, pelaksanaan pungsi lumbal masih kontroversi, dianjurkan dilakukan pada bayi yang menderita kejang, kesadaran menurun, klinis sakit tampak makin berat dan kultur darah positip.

- Bila ada indikasi, dapat dilakukan biakan tinja dan urin.

- Pemeriksaan apusan Gram dari bahan darah maupun cairan liquor, serta urin.

- Lain-lain misalnya bilirubin, gula darah, dan elektrolit (natrium, kalium).

\section{Pemeriksaan Radiologi}

Pemeriksaan radiologi yang diperlukan ialah foto dada, abdomen atas indikasi, dan ginjal. Pemeriksaan USG ginjal, skaning ginjal, sistouretrografi dilakukan atas indikasi.

\section{Pemeriksaan Penunjang Lain}

Pemeriksaan plasenta dan selaput janin dapat menunjukkan adanya korioamnionitis, yang merupakan potensi terjadinya infeksi pada neonatus.

\section{Tatalaksana}

1. Pencegahan dilakukan dengan memperhatikan pemakaian jarum atau alat tajam lainnya sekali pakai. Pemakaian proteksi di setiap tindakan, termasuk sarung tangan, masker, baju, kacamata debu. Tangan dan kulit yang terkena darah atau cairan tubuh lainnya segera dicuci.

2. Pengobatan

Penisilin atau derivat biasanya ampisilin $100 \mathrm{mg} /$ $\mathrm{kg} / 24 \mathrm{jam}$ intravena tiap $12 \mathrm{jam}$, apabila terjadi meningitis untuk umur 0-7 hari $100-200 \mathrm{mg} / \mathrm{kg} /$ $24 \mathrm{jam}$ intravena/intramuskular tiap $12 \mathrm{jam}$, umur $>7$ hari $200-300 \mathrm{mg} / \mathrm{kg} / 24 \mathrm{jam}$ intravena/ intramuskular tiap 6-8 jam, maksimum $400 \mathrm{mg} /$ $\mathrm{kg} / 24$ jam.

Ampisilin sodium/sulbaktam sodium (Unasyn), dosis sama dengan ampisilin ditambah aminoglikosid $5 \mathrm{mg} / \mathrm{kg} / 24 \mathrm{jam}$ intravena diberikan tiap $12 \mathrm{jam}$. Pada sepsis nosokomial, sebaiknya diberikan vankomisin dengan dosis tergantung umur dan berat badan:

- $\quad<1,2 \mathrm{~kg}$ umur 0-4 minggu: $15 \mathrm{mg} / \mathrm{kg} / \mathrm{kali}$ tiap $24 \mathrm{jam}$ 
- $\quad 1,2-2 \mathrm{~kg}$ umur 0-7 hari: $15 \mathrm{mg} / \mathrm{kg} / \mathrm{kali}$ tiap 12 18 jam

- $\quad 1,2-2 \mathrm{~kg}$ umur $>7$ hari: $15 \mathrm{mg} / \mathrm{kg} / \mathrm{kali}$ tiap 8 $12 \mathrm{jam}$

- $\quad>2 \mathrm{~kg}$ umur 0-7 hari: $15 \mathrm{mg} / \mathrm{kg} / \mathrm{kali}$ tiap $12 \mathrm{jam}$

- $\quad>2 \mathrm{~kg}$ umur $>7$ hari: $15 \mathrm{mg} / \mathrm{kg} / \mathrm{kali}$ tiap 8 jam ditambah aminoglikosid atau sefalosporin generasi ketiga

3. Terapi lanjutan disesuaikan dengan hasil biakan dan uji resistensi.

4. Pengobatan komplikasi

- Pernapasan: kebutuhan oksigen meningkat, yang harus dipenuhi dengan pemberian oksigen, VTP atau kemudian dengan ventilator.

- Kardiovaskular: menunjang tekanan darah dan perfusi jaringan, mencegah syok dengan pemberian volume ekspander $10-20 \mathrm{ml} / \mathrm{kg}$ $(\mathrm{NaCl} 0,9 \%$, albumin dan darah). Catat pemasukan cairan dan pengeluaran urin. Kadang diperlukan pemakaian dopamin atau dobutamin.

- Hematologi: untuk DIC (trombositopeni, protrombin time memanjang, tromboplastin time meningkat), sebaiknya diberikan FFP $10 \mathrm{ml} / \mathrm{kg}$, vit $\mathrm{K}$, suspensi trombosit, dan kemungkinan transfusi tukar.

Apabila terjadi neutropeni, diberikan transfusi neutrofil

- Susunan syaraf pusat: bila kejang beri fenobarbital $(20 \mathrm{mg} / \mathrm{kg}$ loading dose) dan monitor timbulnya sindrom inappropriate antidiuretic hormon atau SIADH, ditandai dengan ekskresi urin turun, hiponatremi, osmolaritas serum turun, naiknya berat jenis urin dan osmolaritas.

- Metabolik: monitor dan terapi hipo dan hiperglikemia. Koreksi asidosis metabolik dengan bikarbonat dan cairan.

Pada saat ini imunoterapi telah berkembang sangat pesat dengan diketemukannya berbagai jenis globulin hiperimun, antibodi monoklonal untuk patogen spesifik penyebab sepsis neonatal.

\section{Daftar Pustaka}

1. Gomella TL. Neonatology. Penyunting $4^{\text {th }}$ ed. Connecticut: Appleton \& Lange 1999:h.408-14.

2. Isaacs D, Moxom ER. Neonatal infection. Penyunting Oxford: Butterworth Heinemann 1991:h.25-39.

3. Korones SB, Bada-Ellzey HS. Neonatal decision making. Penyunting $2^{\text {nd }}$ ed. Missouri: Mosby Year Book 1993:h.104-11.

4. Neonatal sepsis and IVIG. http://www.ucs.mun.ca/ -skhoury/ivig.html.

5. Polin RA, Yoder MC, Burg FD. Practical neonatology. Penyunting, $2^{\text {nd }}$ ed. Philadelphia: WB Saunders Company 1993:h.227-49.

6. Staf Pengajar Ilmu Kesehatan Anak, Fak. Kedokteran UI. Buku Kuliah Ilmu Kesehatan Anak jilid 3 Fakultas Kedokteran Universitas Indonesia, Jakarta 1995:h.112331. 
Algoritme 1

Transmisi infeksi bakteri melalui materno-fetal (transmisi vertikal)

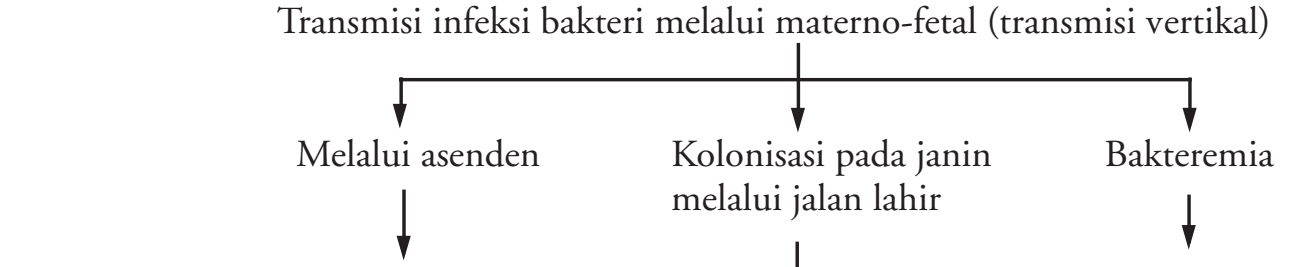

Persalinan

ketuban pecah

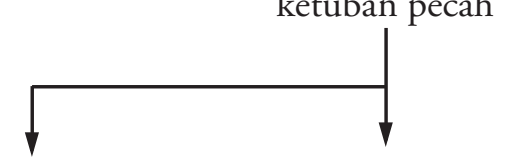

Ketuban pecah dini $\rightarrow$ Organisme vagina

Persalinan lama

dan servix masuk

Infeksi jalan lahir

ke dalam cairan ketuban

$\downarrow$<smiles>[CH]1C=CCC1</smiles>

Inokulasi berat $\longrightarrow$ Organisme multiplikasi

Dalam cairan ketuban

korioamnionitis

Ruangan intervilus

$$
t
$$

Vilus korion

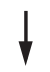

Sepsis pada janin

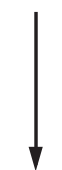

Sepsis neonatal

waktu lahir atau

segera setelah lahir

Organisme masuk ke

dalam sal. pernapasan

$\&$ sal. pencernaan

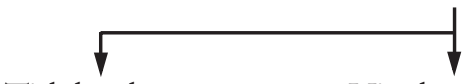

Tidak ada

Virulensi bakteri

penyakit neonatal

Inokulasi berat

Pertahanan tubuh terganggu

Prematuritas

$$
\downarrow
$$

Timbul penyakit sejak dalam uterus dan dalam 72 jam setelah lahir

\section{Timbul penyakit} neonatal 24-72 jam setelah lahir

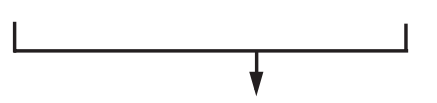

Pneumonia

Sepsis

Meningitis

Otitis media

Konyungtivitis

Bagan 1. Algoritme transmisi bakteri materno - fetal 


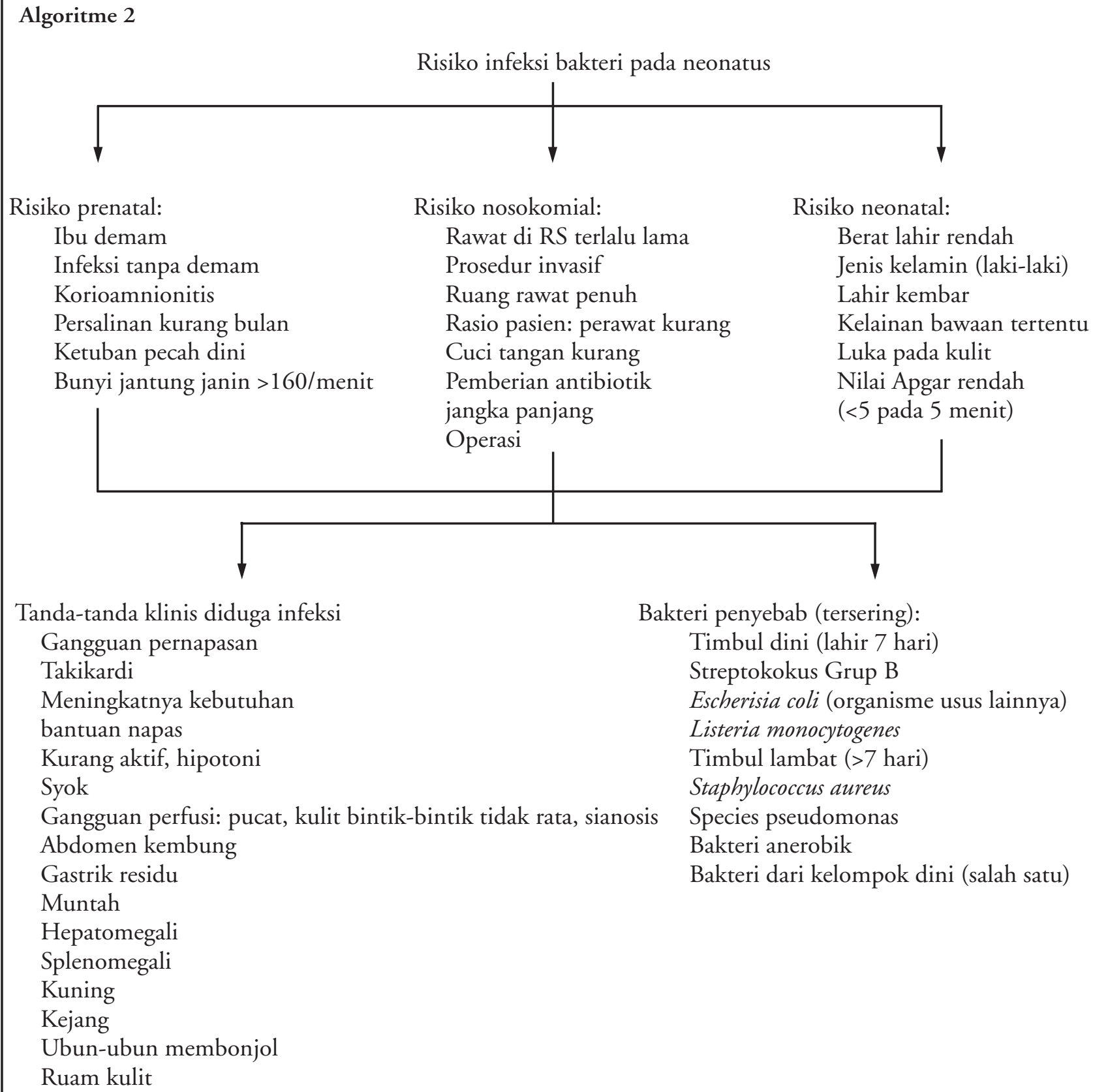

Risiko prenatal: $\quad$ Risiko nosokomial:

Ibu demam

Infeksi tanpa demam

Korioamnionitis

Persalinan kurang bulan

Ketuban pecah dini

Bunyi jantung janin $>160 /$ menit

Tanda-tanda klinis diduga infeksi

Gangguan pernapasan

Takikardi

Meningkatnya kebutuhan

bantuan napas

Kurang aktif, hipotoni

Syok

Gangguan perfusi: pucat, kulit bintik-bintik tidak rata, sianosis

Abdomen kembung

Gastrik residu

Muntah

Hepatomegali

Splenomegali

Kuning

Kejang

Ubun-ubun membonjol

Ruam kulit

Rawat di RS terlalu lama

Prosedur invasif

Ruang rawat penuh

Rasio pasien: perawat kurang

Cuci tangan kurang

Pemberian antibiotik

jangka panjang

Operasi

Risiko neonatal:

Berat lahir rendah Jenis kelamin (laki-laki)

Lahir kembar

Kelainan bawaan tertentu

Luka pada kulit

Nilai Apgar rendah

(<5 pada 5 menit)

Bakteri penyebab (tersering):

Timbul dini (lahir 7 hari)

Streptokokus Grup B

Escherisia coli (organisme usus lainnya)

Listeria monocytogenes

Timbul lambat ( $>7$ hari)

Staphylococcus aureus

Species pseudomonas

Bakteri anerobik

Bakteri dari kelompok dini (salah satu)

Bagan 2. Algoritme pendekatan infeksi bakteri pada neonatus 


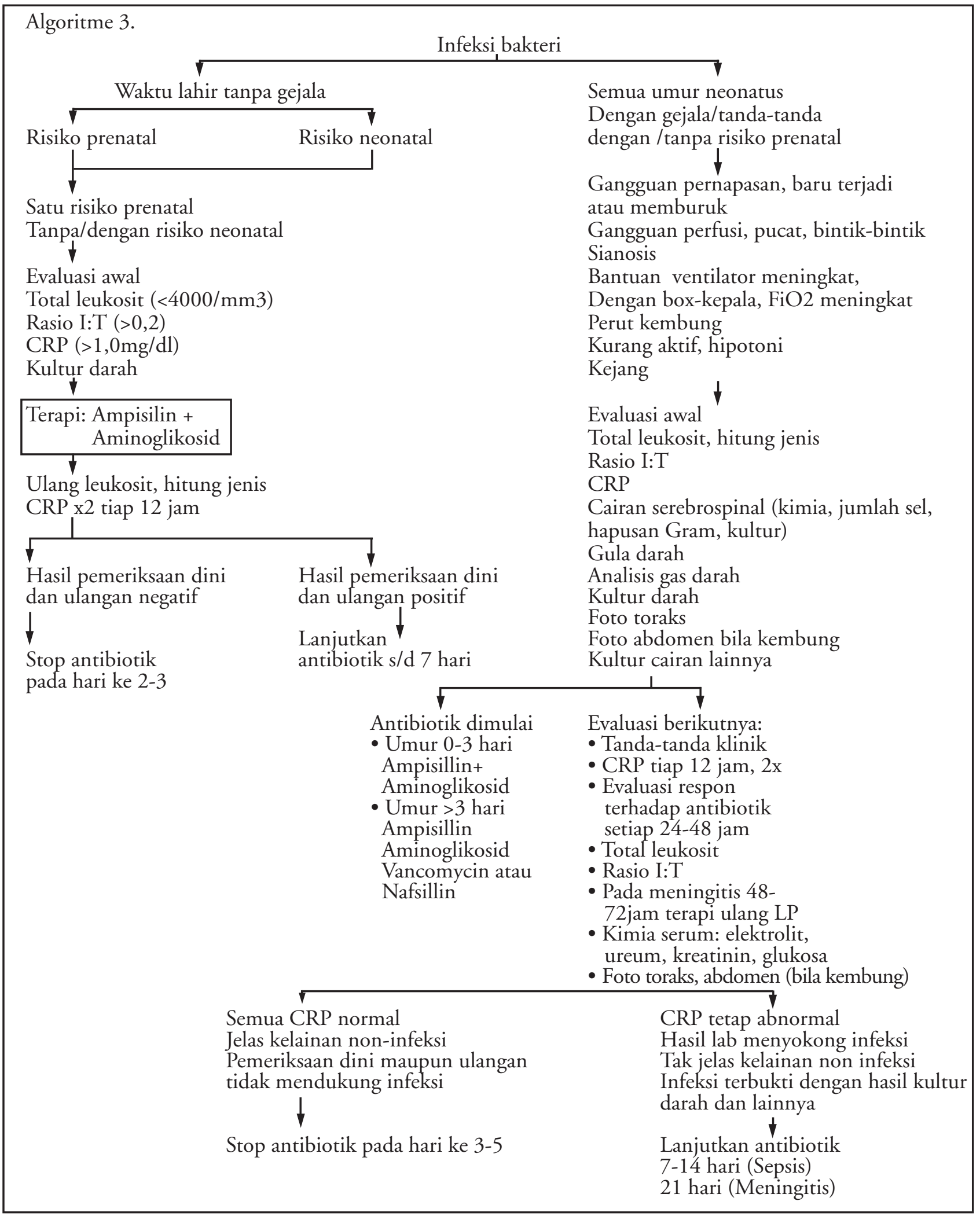

Bagan 3. Algoritme tatalaksana infeksi bakteri pada neonatus 